\title{
Religion and the Japanese Constitution
}

\section{Citation}

Hardacre, Helen. Forthcoming. Religion and the constitution of Japan. In Constitution writing, religion and democracy, ed. Aslı Bâli and Hanna Lerner. Cambridge: Cambridge Univ. Press.

\section{Permanent link}

http://nrs.harvard.edu/urn-3:HUL.InstRepos:12308970

\section{Terms of Use}

This article was downloaded from Harvard University's DASH repository, and is made available under the terms and conditions applicable to Other Posted Material, as set forth at http:// nrs.harvard.edu/urn-3:HUL.InstRepos:dash.current.terms-of-use\#LAA

\section{Share Your Story}

The Harvard community has made this article openly available.

Please share how this access benefits you. Submit a story.

Accessibility 


\title{
Religion and the Japanese Constitution \\ Helen Hardacre \\ Harvard University
}

\begin{abstract}
This paper examines provisions regarding religion in the 1947 Constitution of Japan, showing how they differ from the Meiji constitution of 1889. It examines policies on religion established by the Allied Occupation of Japan (1945-1952), especially relating to Shinto, their implementation, and their relation to the 1947 constitution. The paper documents the process through which Occupation officials drafted entirely new articles on religion, displacing a Japanese government commission that was working to revise the Meiji constitution. The paper shows that while in post-Occupation discussions of constitutional revision, issues concerning religion have not been controversial, recent proposals for a revised constitution would introduce significant changes.
\end{abstract}

\section{Introduction}

The present Constitution of Japan (Nihon koku kenpō) was drafted under military occupation in 1946 and promulgated in 1947; I will refer to this document as 'the postwar constitution'. The document is formally regarded as a revised version of the 1889 Constitution of the Empire of Japan (Dai Nihon Teikoku Kenpō, hereinafter, 'the Meiji constitution', so called because it was issued during the Meiji period, 1868-1912). In fact, however, the content and orientation of the two constitutions are so different that for all practical purposes it makes sense to think of them as separate. This is especially true of their provisions for religion. 
The Meiji constitution addressed religion in article 28: "Japanese subjects shall, within limits not prejudicial to their duties as subjects, enjoy freedom of religious belief." It is apparent that freedom of belief is limited, and trumped by other "duties," though these are not specified. This article was modeled on European constitutions in the late nineteenth century that commonly placed some restriction on the exercise of religious freedom. The Meiji constitution did not adopt the principle of separation of religion from state. The postwar constitution's provisions on religion are entirely different:

Article 20: Freedom of religion (shinkyō no jiyū) is guaranteed to all. No religious organization shall receive any privileges from the state, nor exercise any political authority. No person shall be compelled to take part in any religious act, celebration, rite, or practice. The State and its organs shall refrain from religious education or any other religious activity.

Article 89: No public money or other property shall be expended or appropriated for the use, benefit or maintenance of any religious institution or association or for any charitable, educational or benevolent enterprises not under the control of pubic authority.

Article 89 serves to clarify separation of religion from state (article 20) by explicitly forbidding public expenditures for religious organizations, religious schools, and charities. Related to these two main articles, article 14 forbids "discrimination in political, economic, or social relations because of ...creed," and article 19 prohibits any violation of freedom of thought or conscience. As these clauses make clear, the postwar constitution upholds the principles of religious freedom without restriction and separation of religion from state. The state may not fund religious activities.

In addition to the constitutional provisions that were in place for religion under the Meiji constitution, related administrative policies also governed religion. For example, since the early 1880s the government of Japan had publicly maintained that Shinto is not a religion. Instead, the bureaucracy in charge of religious affairs promoted Shinto as a public 
expression of Japanese ethnic identity and loyalty to the throne that all imperial subjects would observe, regardless of their private religious beliefs. The assertion that Shinto belongs to the public realm placed it above the private sphere of religion and included the idea that Shinto is an element of governance providing the rites of state, because it embodies Japan's indigenous tradition.

The bureaucracy promoted Shinto as the source of the ancient rites of state performed by the emperor. These included an annual calendar of palace ritual as well as enthronement rites. Early in the Meiji period, the new government had legitimated itself by making the emperor its chief symbol. The new government distinguished itself from its predecessor, the Tokugawa shogunate that had ruled from 1600 to 1868, by rejecting the shogunate's promotion of Buddhism. The new Meiji government promoted Shinto instead through a variety of draconian policies. One of these was to excise all Buddhist ritual from shrines and the palace, and to revive much of the ancient annual calendar of imperial ritual for the Kami, the deities of Shinto. In addition, the roughly 80,000 Shinto shrines were organized into a unified ranking system and instructed by the bureaucracy to stage ritual mirroring those performed by or for the emperor. The purpose was to create a ritual system that would unify the entire nation in a spirit of reverent support for the emperor and his government. This unification of the shrines under government administration, a common ranking system, their separation from Buddhism, the use of them to promote patriotism, and the institution of a common ritual calendar for them were revolutionary in the history of Shinto, one of the great watersheds in the history of religion in Japan.

Seen in this light, State Shinto was an entirely novel creation, and the view of the Occupation, that the government had misused or twisted Shinto to its own ends had much 
truth to it. On the other hand, claims for public status and roles in governance based on the performance of state ritual, as well as the claim that Shinto uniquely embodies indigenous tradition, had been made throughout the longer history of Shinto. By contrast, the idea of "religion" as a competing element of the private sphere was novel in the late nineteenth century, and from a Shinto perspective it was consistent to deny the idea that Shinto was one of the religions and hence something that a Japanese subject would be free to reject.

The affirmation by the priesthood of the idea of Shinto as a non-religious phenomenon caused a bitter controversy in the academy. By the late nineteenth and twentieth centuries, however, the populace's devotional attitude towards the divinities of Shinto, known as Kami, expressed in prayers, ceremonies, and festivals of Shinto shrines, was widely acknowledged among scholars to be religious, by any definition, whatever the priesthood might claim regarding its performance of state ritual. In the view of scholars outside the shrine priesthood, the fiction of Shinto's non-religious nature had been formulated by bureaucrats intent upon lifting Shinto's state rites relating to the emperor and the nation above the contentious sphere of religious teachings.

Western scholars of Japanese religions in prewar Japan such as Daniel Holtom (1884-1962) ${ }^{1}$ adopted a view of Shinto that was highly influential with the Allied Occupation. In his 1943 work, Modern Japan and Shinto Nationalism: A Study of PresentDay Trends in Japanese Religions, ${ }^{2}$ Holtom asserted that Shinto promotes nationalism and militarism. Since the Japanese bureaucrats' fondest hope for Shinto was that it would promote patriotic loyalty, it is not surprising that Holtom came to this conclusion. He was right, though in his concentration on Shinto, his work did not address the equally important 
fact that all branches of religion in Japan sought to do the same and competed with each other in doing so.

The shrine priesthood flourished under government patronage, and shrine rites became a staple observance of Japanese society as a whole. From 1868 until the Allied Occupation of Japan commenced in 1945, Shinto grew and prospered under bureaucratic supervision based on the idea of Shinto as a public entity with a rightful role in government and as embodying indigenous Japanese tradition. Shinto during this period was so closely allied with the state that it is referred to as "State Shinto." Because Shinto flourished during this era, the priesthood bitterly resented the Occupation's relegation of Shinto to the private sphere of religion and its ejection of Shinto from government after. The official priestly body, the National Association of Shinto Shrines (founded in 1945), seeks in a variety of ways even today to recover Shinto's lost public roles.

\section{Occupation Policies Regarding Shinto}

Planning for the Occupation of Japan had begun in late 1943, when the U.S. State Department began to plan post-surrender policies. This body worked intensively, meeting over 200 times by July 1945. ${ }^{3}$ The Potsdam Declaration of 26 July 1945 dictated the terms of Japan's unconditional surrender and announced that freedom of religion would be established. After the surrender, Shinto leaders were extremely fearful of the Occupation's intentions regarding Shinto. Many believed that the Occupation intended to abolish Shinto completely. According to one popular account, it was rumored at the end of the war that all shrine priests would be executed because of their close connections with the military. ${ }^{4}$ 
The Occupation's initial policies on religion were specified for the Supreme Commander, General Douglas MacArthur, on 21 September 1945 in the document "U.S. Initial Post-Surrender Policy for Japan," which stated,

"Freedom of religious worship shall be proclaimed promptly on Occupation. At the same time, it should be made plain to the Japanese that ultranationalistic and militaristic organizations and movements will not be permitted to hide behind the cloak of religion,"

and further, "You will require the Japanese Government to cease financial aid and other support of National Shinto establishments."

From August through December 1945, the Occupation personnel assigned to deal with religion concerned themselves almost solely with Shinto. The Occupation set up its Civil Information and Education Section (CIE) on 22 September 1945, headed by Colonel (later, Brigadier General) Ken R. Dyke, subsequently establishing Divisions within it relating to religion and education. The Religions Division was headed by Lieutenant William Kenneth Bunce (1907-2008). Bunce was the official with whom Shinto representatives most closely interacted. ${ }^{5}$ Another central staff member of the Religions Division was William P. Woodward, who served from May 1946 through the end of the Occupation. ${ }^{6}$

Drafting the Postwar Constitution Begins

It is important to understand that the Occupation's Religions Division did not interact with the several projects aiming to draft a new constitution. Constitutional drafting and the administration of religious affairs proceeded on separate tracks. The Supreme Commander of the Allied Forces, General Douglas MacArthur, first approached Prince 
Konoe Fumimaro to begin drafting in October of 1945, but Konoe committed suicide when it became apparent that he would face charges as a war criminal. ${ }^{7}$ Around the same time that MacArthur approached Konoe, the Japanese government appointed scholar Matsumoto Jōji, a scholar of commercial law, to head a body titled, "Constitutional Issue Investigation Committee." The title did not incorporate the word "revision," based on the government's hope that it might be merely to issue somewhat more liberal guidelines for interpreting the Meiji constitution instead of tampering with the text.

\section{The Shinto Directive}

Meanwhile, the Religions Division was working towards one of the Occupation's most consequential policies in religion, the Shinto Directive. This policy was meant to be superseded by the constitution, but in fact the relation between Shinto and state that the Directive established became set in stone and accepted completely by subsequent constitutional interpretation (e.g., in post-Occupation Supreme Court cases regarding religion). This means that we cannot fully grasp the constitution's implications for Shinto without understanding the purpose, substance, and implementation of the Shinto Directive.

The State Department group planning for the Occupation sent the "Memorandum: Freedom of Worship" to the Supreme Commander in October 1945. It called for a prompt declaration of religious freedom but predicted that it would be difficult to implement it with respect to Shinto, "in view of the difficulty of differentiating Shintoism, as a religion, from extreme Nationalism."8 Pre-surrender planners intended that all Shinto shrines be permitted to continue, and there were no plans to abolish any of the roughly 80,000 
shrines, including Yasukuni Shrine, national shrine for the war dead. ${ }^{9}$ In fact, the Occupation did not destroy or even close a single shrine.

Meanwhile, Bunce had begun intensive study of Shinto in order to prepare the directive. He drew considerably on the works of Daniel Holtom, ${ }^{10}$ also consulting with Tokyo Imperial University professor of comparative religions Anesaki Masaharu. During the period when he was preparing the draft of the Shinto Directive, Bunce was most closely associated with Kishimoto Hideo (1903-1964), son-in-law and former student of Anesaki, then an assistant professor at Tokyo Imperial University. Kishimoto, who had spent the years 1930 to 1934 at Harvard, had been drafted to facilitate CIE's communications with Japanese experts, scholars, and government offices relating to education and religion. ${ }^{11}$

On some ten occasions, Bunce had Kishimoto make presentations on Shinto, while Bunce put questions to him. Kishimoto also arranged visits for Bunce and Dyke to visit various sites to observe religious life in situ. If Kishimoto proved unable to answer their questions, he would locate an expert who could respond. It became clear to Bunce over these sessions that Shinto was a wide-ranging, polymorphous tradition that could not be comprehended solely through slogans like militarism and nationalism. ${ }^{12}$

The question of the Yasukuni Shrine remained distinctly problematic, however, and there was an element in the Occupation that favored closing it. A Special Enshrinement Service was planned for 20 November 1945, to apotheosize around two million war dead. The question arose whether the Occupation should cancel it, given that the large scale of the event and the prospect of the emperor attending. Dyke determined to attend the ceremony with Bunce, to see for himself whether Yasukuni promoted militarism. Kishimoto made the arrangements, which involved complex negotiations with the shrine and military 
officers, who were planning to appear in full uniform, despite their demobilization. Kishimoto was able to persuade them to eliminate certain elements of military pomp, based on his belief that Dyke might well make critical decisions on Yasukuni's future, based on what would happen at the ceremony. In the end, Dyke and Bunce attended the ceremony, after which they had lunch with the Head Priest. ${ }^{13}$ They found the ceremony unproblematic.

Wartime propaganda had doubtless prepared Dyke and Bunce to believe that Shinto might be equated with militarism and nationalism. Through their investigations, however, as well as Kishimoto's tutelage and that provided by other Japanese scholars, complemented by the opportunity to observe religious life at a number of shrines, the occupiers' views became more nuanced and their understanding more sophisticated. This interaction among Occupation officials, Japanese scholars, and religious leaders was not always easy, but its results were generally positive.

It bears noting, however, that the emerging view of Shinto reached within the Religions Division over the period from late October through November 1945 was inevitably lopsided when it came to the question of militarism or nationalism and Japanese religions. The Religions Division was so focused on Shinto at this time, so intent on clarifying Shinto's contribution to militarism and nationalism, that it would have been unlikely to realize that virtually all other branches of Japanese religions up to $1945 \mathrm{had}$ similarly devoted themselves to prayers for military victory, exaltation of the martial spirit, and justification of Japan's supposed mission to rule all of Asia. In other words, singleminded focus on Shinto in these crucial weeks inevitably underlined Shinto's connection with militarism and nationalism and equally inevitably obscured that same connection in 
other branches of religion. The result in Woodward's words was that, "Shinto became the whipping boy of the Occupation."14

Moreover, Bunce was unable to sample public opinion regarding the status of Shinto and shrines as part of the investigations that informed his drafting. The greatest reason was the policy of press censorship, which forbade any criticism of the Occupation. The newspapers provided virtually no coverage of Shinto until Bunce was well along in his research. Even then, press coverage was largely devoted to views of Shinto seen in the foreign papers. A single opinion piece appearing in the Asahi on November 12 , by Takashima Beihō, a Buddhist leader known as a reformer, championed the idea that Shinto is not a religion. While Bunce undoubtedly was informed of this article, he had already rejected the author's position. ${ }^{15}$

Whenever a directive was to be issued, a staff study of it was composed, a document which would explain its necessity and its aims to the Chief of Staff. Staff studies included whatever information would be needed in order to explain the directive to the Supreme Commander, as well as information necessary for the Japanese government to implement the directive. The staff study accompanying the Shinto Directive, dated 3 December 1945,16 explains, "State Shinto has been used by militarists and ultranationalists in Japan to engender and foster a military spirit among the people and to justify a war of expansion." While noting that the defeat has considerably undermined Shinto's political potential, the report continues, Shinto will remain a danger until it is completely separated from the state and eliminated from the schools.

The government's misuse of Shinto consisted of inserting it into the schools:

"Through the medium of textbooks, highly indoctrinated teachers, and deeply impressive ceremonies, Shinto was made the principal instrument for inculcating 
submissiveness, loyalty to the state, and unquestioning acceptance of the officials views....Good citizenship was identified with acceptance of Shinto mythology."17

The report states conclusively that State Shinto was a religion. Though it did not have specific doctrines, it stood for a belief in the superiority of Japan, the emperor, and the Japanese, worship of the emperor as a living god, and the belief that Japan had a mission to rule Asia. ${ }^{18}$ State Shinto was called dangerous, inasmuch as the beliefs for which it stood might be revived and used by some future Japanese government to instill sentiments of militarism and imperialism. The problem will be eliminated, however, if State Shinto is removed from the schools and strictly separated from the state. Significantly, the report foresaw no particular problem in the ongoing connections between Shinto and the imperial house.

The report concluded with several specific recommendations for severing the relation between the state and Shinto and for eliminating it from the schools: complete severing of the shrines from public support; treatment of Shinto as a religion; elimination of government control or direction of the shrines, placing Shinto on an equal footing with other religions; elimination of the Shrine Institute (Jingiin), the bureaucratic office created in 1940 to deal with shrine affairs; removal of all Shinto elements from public schools, including nationalist interpretations of the Imperial Rescript on Education; removal of Shinto altars (kamidana) from schools and public offices; and abolition of compulsory school trips to shrines. The report further recommended that the emperor issue a rescript repudiating all notions of Japanese superiority and the idea that Japan has a mission to rule in Asia.

The directive required that the following cease immediately: all use of public funds for Shinto, all propagation and dissemination of militaristic ideology in Shinto-and all 
religions'-doctrines, practices, rites, and ceremonies, public educational institutions devoted to Shinto or to Shinto priests' training, and any dissemination of Shinto doctrines in schools. Circulation of nationalistic tracts (for example, Kokutai no hongi) was ordered stopped, and the use of terms such as "Greater East Asia War" (dai tōa sensō) and "The Whole World Under One Roof" (hakkō ichiū) were prohibited. Shinto altars (kamidana) and other ritual gear were ordered removed from public buildings of all kinds, especially schools. No person was to be discriminated against because of refusal to profess belief in Shinto or because of refusal to participate in any Shinto ceremony. Public officials were to cease the practice of visiting shrines to report their assumption of office. All religions were to be put "upon exactly the same basis, entitled to precisely the same opportunities and protection."

The directive repeatedly forbade "militaristic and ultra-nationalist ideology," which it defined as doctrines of the superiority of the emperor, the Japanese people, and the Japanese islands, as well as any doctrine "which tends to delude the Japanese people into embarking upon wars of aggression or to glorify the use of war as an instrument for the settlement of disputes with other peoples." 19

While the directive became known informally as one exclusively concerned with Shinto, it went some distance toward a wider declaration of separation of religion from state, inasmuch as all religions (Shinto included) were prohibited from "affiliation with the government." It thus had a universal character that went beyond Bunce's mandate regarding Shinto. ${ }^{20}$

The Japanese government moved swiftly to comply with the Shinto Directive, issuing orders within days to the prefectures to suspend all the prohibited practices. The 
Ministry of Education removed kamidana from the schools and references to religion from their textbooks. Ethics courses were suspended..$^{21}$ The Tokyo Imperial University Chair of Shinto was abolished. On 15 March 1946, the Japanese government reported that appropriate consultations at all levels had been held, and public support for Shinto removed from the budget. The Occupation was very satisfied with the Japanese government's compliance with the Shinto Directive.

The government and the military were named as the agents behind Shinto's misuse, but without naming names or even a government ministry. Neither the priesthood nor Shinto scholars were singled out for punishment, though some were briefly "purged," which is to say required to refrain from public activity for a period of time. No specific blame was assigned for the misuse of Shinto that the directive claimed was carried out from the Meiji period through 1945.

Both the Shinto Directive and the staff study that preceded it tacitly absolved the Shinto world of responsibility for its "misuse" and "perversion" by the Japanese government and the military. But what of the people's roles in Shinto's transformation? The directive treated the people as virtually passive onlookers or victims, as lacking agency to change the course of events. No particular person seemed to bear any responsibility. The fuzzy image of a religion seized upon by government and molded to its ends, with no specific agency attributed to anybody in the bureaucracy, to the priesthood, or the people, became part of the popular narrative of Shinto's modern history. State Shinto was apparently something that "just happened" to the priests and the people.

How was the Shinto Directive received in Japanese society? Newspaper coverage was minimal and showed most interest in the question whether the emperor would be 
forced to abdicate or the imperial system eliminated altogether. Certainly there were no protests, but since the directive was issued a mere four months after the surrender, concerns about surviving from one day to the next were still uppermost in everyone's mind. Moreover, Occupation censorship meant that that even if someone had violently disapproved of the Shinto Directive, protest was unlikely.

In the Diet, the Shinto Directive was not even mentioned before 1949, suggesting that legislators did not find it especially problematic. However, especially early in the Occupation, Diet members' commentary on anything related to shrines was remarkably circumspect and brief. This suggests that even if Diet discussion was not subject to censorship (meaning that submission of remarks to Occupation officials in advance for their approval was not required), a sort of self-censorship was practiced.

The Yomiuri newspaper used its 18 December 1945 editorial to declare that the Shinto Directive removed "a veil of mystery" from Shinto, shedding new light on the causes of Japan's deplorable condition. Although there were those in the educated classes who must have doubted Shinto's "mysticism" (shinpisei), no one had the "power" (chikara) to challenge it, from scholars to socialists to the labor unions. This passivity allowed the bureaucrats and the military to twist Shinto into a philosophy of Japan's mission for world domination, leading to war and utter defeat. Now that the veil has been lifted, however, the people should take this as an occasion to rebuild the country and "reform its history," beginning with the emperor system, since Shinto has taken the emperor as its head priest. $^{22}$ In this editorial as well, it appears that the "veil of mystery" came out of nowhere and descended on Shinto in a way that made it impossible to question. No one was at fault. 
The newspaper certainly did not raise the possibility that the media bore any responsibility. Since everyone was equally a victim, there were no perpetrators.

Reception of the Shinto Directive by the shrine priesthood was overwhelmingly negative, however, and criticism of it remains a staple of Shinto scholarship even at the beginning of the twenty-first century. While both the Shinto Directive and the staff study that preceded it tacitly absolved the Shinto world of responsibility for its "misuse" and "perversion" by the Japanese government and the military, this apparent absolution left the clear implication that the priesthood had either been incapable of defending the tradition or complicit in its misuse. ఏinja shinpō, newspaper of the Association of Shinto Shrines, even now continues critique of the Directive for impugning Shinto's honor and failing to understand how Shinto was itself victimized in its appropriation by the state.

Implementation of the Shinto Directive in Japanese society revealed both that the attitudes the directive sought to eradicate were deeply rooted and not easily changed, and also that citizens quickly adopted it as a standard that could assist them in rejecting ongoing coercion to support shrines monetarily. The Occupation received many complaints about violations of the Directive. ${ }^{23}$

The complaints took several forms. The Japanese state broadcasting company (Nihon Hōsō Kyōkai) aired one woman's account on a program examining public opinion in August 1946:

We had a festival...last month and as usual. On the day before the festival, several women were sent to the shrine from the neighborhood association to clean the sacred palanquin, to weed the precincts, and to haul fuel on a big cart. While they were doing this, the men sat in the shrine doing nothing but drinking tea, smoking, counting talismans, and making cut papers to be hung in the shrine. This is an ancient custom of the village and no one can protest. 
This year on the morning of the day before the festival, a circular written on two sheets of paper came to my house. It listed the names of the heads of the families in the village and gave the responsibilities assigned to each...But this made us angry, and we left it with a laugh. We thought we had been given religious freedom and that there was not reason to submit to such pressure. However, on the afternoon of the festival day the head of the group (the former head of the neighborhood association) came to me and said, "I have come to collect your contribution to the festival. Though you have three families here, none is helping the festival, so you should contribute 300 yen...." When I asked, "Why do we have to make this contribution?" he answered: "To repair the shrine. The shrine needs a large sum of money...."

While the so-called managers of the festival drink until very late at night and bother the neighbors, I have been waiting these six years for my husband's return from abroad. [Presumably he was being held in the USSR]. I have an invalid old father and a brother on public relief. Still worse, my elder sister, who is a war widow, has joined my family with her children. We are able to lead only a very meager life by sewing and making paper bags. How can we contribute 300 yen?"

This was a serious matter for a 'woman's household' like ours, and I was anxious at the time about the money for our rations which were to be issued the next day. So when he said that, I thought of my old father and my poor elder sister with her children and I determined to make a contribution. But I had no money, and there was nothing else to do, so I went to a money-lender. ${ }^{24}$

As the woman's complaint makes clear, relatives displaced by the recent war and bombing campaigns piled in together to somehow make a living, however lean. The fact that the speaker's father, brother, sister and the sister's children were living with her led the neighborhood to assess her for three families' contributions to the shrine. It was further galling to her that the women of the community were called out for the backbreaking work of weeding and hauling fuel, while the men spent a leisurely day folding paper and drinking tea, followed by nighttime carousing that disturbed everyone else. Pressured by the former head of the neighborhood association, however, she decided to make the requested contribution even though she had to take a loan to do it. Why did she go along, when she could have refused? The factor she mentions in closest proximity to the decision is her anxiety about rations. After the defeat, the cities of Japan faced desperate 
food shortages, and those did not ease substantially until 1949. The neighborhood associations delivered rationed food. The woman speaker seems to have feared that the man pressuring her for a contribution to the shrine might have interfered with the delivery of the rations on which her large household depended. Notably, she fears a representative of the neighborhood association acting on behalf of a shrine, not a shrine priest. In any case, the Shinto Directive was issued to deal with precisely this sort of problem.

The Supreme Commander Takes Control of Constitution Drafting

On February 1,1946, the Mainichi newspaper published an account of the drafting work of the Matsumoto committee, revealing that it envisioned making only cosmetic changes to the Meiji constitution. The work of Matsumoto's group was confined to the existing text of the Meiji constitution, and they contemplated making as little change as possible. Popular reaction to what had been leaked of the Matsumoto revision was lambasted in the press as lame, watered-down, and scarcely making any difference. ${ }^{25}$ For example, the Matsumoto committee planned this revision for article 28 of the Meiji constitution:

Every Japanese subject shall have freedom of religious belief and the restrictions necessary to maintain public peace shall be under the provisions of the law.

Notation: No protection to other persons than Japanese subjects.

The special privileges that every shrine has ever had shall be abolished. ${ }^{26}$

The Matsumoto draft showed evident intent to persist in calling the Japanese people "subjects" of His Majesty rather than citizens, and it clearly expected to continue the limitation on religious freedom by unspecified "restrictions" justified as necessary to maintain public order. No mention was made of separation of religion from state. 
Moreover, in denying constitutional protection to non-citizens, the draft abdicated responsibility for the rights of any former colonial subjects who might press a grievance, as well as to other non-Japanese residing in Japan. Its reference to abrogating "special privileges" to Shinto shrines was the least possible bow to the Shinto Directive, which was already in force.

MacArthur, for whom, as Dower notes, "the line between Supreme Commander and Supreme Being was always a fine one," was unwilling to wait to see the full results of Matsumoto's handiwork. Two days later, MacArthur ordered the Government Section of the Occupation to convene a group to draft an independent version within one week. They were to ignore the framework of "revision" to the Meiji constitution and start afresh. MacArthur charged them to come up with a new constitution that would include clauses in which Japan would preserve the imperial institution, renounce war, and eliminate militarism and "feudalism."

No one could have been more surprised by this turn of events than the 24 members (16 officers and 8 civilians) of the hastily assembled drafting group, headed by Colonel Charles Kades. While four of them (including Kades) had been attorneys in civilian life, none had experience in constitutional law, though it is worth recalling that Matsumoto had specialized in commercial law before being ordained head drafter of revisions by the Japanese government. Only two had lived in Japan: Harry Emerson Wildes (a civilian with some prewar experience of Japan) ${ }^{27}$ and the youngest woman of the group (there were four women in all), Beate Sirota (later, Gordon), born in Vienna but raised in Japan, ${ }^{28}$ fluent in the language, and charged to draft the provisions affecting women. The officer primarily responsible for drafting the "civil rights" section was Lieutenant Colonel Pieter Roest (a 
professor of social science). ${ }^{29} \mathrm{He}$ and Wildes signed the final document conveying the draft to MacArthur under the section for civil rights; Beate Sirota was also a member of this section but did not sign. ${ }^{30}$

The drafters worked in a ballroom in the Dai-Ichi Building in Tokyo, where officers were quartered. They worked in complete secrecy, barring all Japanese from access and locking their papers in a safe each night. The clauses on religion were produced on February 8, 1946, in consultations between the steering committee and the civil rights section. Evidently the civil rights section had produced a draft (apparently destroyed after the meeting) in which Article XIII dealt with religion. The secret "Steering Committee Minutes - 5, 6, 7, 8, 9, 11 and 12 February 1946" are our sole record of how the postwar constitution's article 20 was born: ${ }^{31}$

7. As originally written Article XIII not only guaranteed freedom of religion but expressedly [sic.] forbid all ecclesiastics from political activity of any kind. The Steering Committee questioned both the wisdom and the practicality of the latter provision. Colonel Kades objected that the denial of political activity to ecclesiastics involved the denial to them of freedom of speech and press as well. A special prohibition of this kind has no place in a Constitution, which should be a Bill of Rights, rather than a Bill of Restrictions.

Colonel Roest stated that this Article was designed to prevent the abuse of spiritual authority to political ends. Japan has been a priest-ridden country for generations and political tyranny has been reinforced by the threat of spiritual punishment. It must be made clear to the Japanese that no political authority is attached to any ecclesiastical organization.

Commander Hussey 32 agreed that people are persuaded to political action by the authority of the church, but pointed out that this is a matter of individual conscience, unlikely to be corrected by constitutional provision or statutory law. The further provision that "no religious body will be recognized as such if under the disguise of religion, it should stir up and practice antagonism to other or should weaken instead of strengthen public order and morality" could be used to justify the suppression of any new religious sect because it might disturb the established public order. On the one hand the Drafting Committee forbids ecclesiastical penetration into politics but on the other, it condones State interference with religion. 
The Article was shortened and amended by the Steering to read as a straight forward [sic.] guarantee of freedom of religion and the separation of church and state. ${ }^{33}$

Debate was a strong element in these daily meetings of the steering committee with smaller groups of drafters. Sometimes, dissenting opinions were issued by those who could not be reconciled to the steering committee's decisions. While Roest apparently wanted to keep in place a Japanese law that forbid priests or clerics of any religion from standing for public office, Kades saw a greater harm in the violation of their rights to free speech that would result and wanted to limit prohibitions. Hussey saw a danger in allowing the statein effect—to define religion by withholding recognition from any it might deem harmful to public order. In both these instances it is clear that the steering committee held liberal views and tended to value unrestricted individual liberties more highly than concerns for public order. The final text of article 20 as adopted by the Japanese parliament was essentially unchanged from that compiled by the Occupation drafters.

\section{Diet Discussion of the Draft Constitution}

The Occupation delivered its English-language draft to representatives of the Japanese government on February 13, 1946. After what Dower terms a "translation marathon," in which a Japanese language version was eventually produced-not without introducing a number of subtle but consequential changes of nuance to the English original-deliberations began in the Diet on June 21, 1946. Both the Occupation and the government of Japan were determined that SCAP's role in producing the draft constitution be kept absolutely secret. SCAP is an abbreviation for the Supreme Commander of the 
Allied Powers, and it is often used to refer to the Occupation as a whole. Once the draft began to be examined in detail, however, SCAP's role became an open secret.

The Diet discussed the SCAP draft as if it were the work of the Japanese government, eventually adopting it with some changes - all of which had to be approved in secret by SCAP, but none of which concerned religion. The constitution was adopted and formally promulgated to the country by the emperor on November 3. It went into effect on May 3, 1947. In the interval between the actual drafting and the formal adoption of the constitution, the Diet discussed most of the articles in some detail, especially those dealing with sovereignty, the emperor, war renunciation, and new rights such as woman suffrage. In searching the digital record of all those deliberations, however, I was not able to locate a single discussion of article 20 or 89 . I conclude from this that the legislators either did not find the clauses problematic or that they found so much else so problematic that whatever problems they found with articles 20 and 89 were crowded out. ${ }^{34}$

\section{Status of Religious Law}

No issues regarding religious law have been raised in relation to Japan's constitution. Buddhist sects can require adherence to precepts recognized within the sect, but these have no legal force, and I know of no instance in which a Buddhist organization has sought to establish official recognition for these rules. Shinto has no analog to religious law, nor has Japanese Christianity or any of Japan's new religious movements. While a small number of mosques and synagogues exist, Islam and Judaism are practiced almost exclusively by immigrants. 
How Has the Japanese Constitution Held Up?

While European constitutions have typically been revised multiple times-dozens of times in the case of Germany-the Japanese postwar constitution has never been revised. While it is widely understood that the constitution was compiled by the Occupation, its emphasis on human rights and general liberality by comparison with the Meiji constitution found widespread acceptance among the Japanese people. Also, the bar for revision is set quite high, requiring a two-thirds majority in both houses of the Diet (article 96). But while the constitution has never actually been revised, constitutional revision has been a permanent feature of post-Occupation politics, mainly for conservatives seeking to exalt the emperor or to alter or excise article 9, in which Japan renounces war. These efforts have consistently been vigorously resisted by the left. The great majority of the people have mainly opposed revision up until around 2000. Survey data now show an almost even split, for and against. Religious groups except for Shinto are mostly opposed to revision, while the Association for Shinto Shrines favors revision. Among some religious groups, article 9, especially, is regarded as a sacred trust that must never be abrogated.

\section{Constitutional Revision and the Clauses on Religion}

McArthur notified the Japanese government in January 1947 that it would be appropriate for the Japanese people 'freely to reconsider the constitution' within two years of its promulgation. The Supreme Commander's statement was widely reported in the press, stimulating the compilation of drafts for revision from the political parties and a variety of civil society groups. Discussion of revision presupposed, however, that the democratic principles of the postwar constitution would be retained, and that there would 
be no returning to anything resembling the Meiji constitution. For that reason, no draconian, anti-democratic drafts were compiled at that time. ${ }^{35}$

A further impetus for national considerations of constitutional revision came with the beginning of the Korean War in June 1950. Most proposals centered on the emperor or war renunciation. For example, in a 1956 bibliography of magazine and journal articles dealing with constitutional revision published by the National Diet Library of Japan, containing about 300 entries, exactly two of them gave any indication in their titles of a focus on religion. By far the majority were concerned either with article 9 or the status of the emperor. ${ }^{36}$

In 1956, Prime Minister Hatoyama Ichirō established the Commission on the Constitution (Kenpō Chōsakai). In 1959 this group compiled a volume of 13 drafts or guidelines for new constitutions, submitted by a variety of non-government groups and individuals. ${ }^{37}$ The majority of entries (8) lack any commentary on religion, suggesting that most of the authors represented were satisfied with the 1947 constitution's provisions in this area. Four of the five remaining drafts constitute a rearrangement of items already in the 1947 constitution, usually adopting its wording without change, neither adding nor subtracting ideas to be found there. Only one draft proposes significant change.

Satomi Kishio's “Dai-Nihonkoku kenpō an" is by far the most elaborate, spreading over several different articles a variety of provisions for religious observances by the people and the emperor. Satomi (1897-1974) was the only author of any of these five drafts to come from a religious background. He was the third son of Tanaka Chigaku (18611939, 田中智学) a major figure of 20th century Nichiren Buddhism, founder of the 
nationalist lay Buddhist group Kokuchûkai (founded 1914). He founded the Nihon Kokutai Gakkai in 1936 and later, a Department of Kokutai Studies at Ritsumeikan University. He also founded a Nichiren lay organization called Risshô Kyôdan (立正教団) in 1956. A prolific writer, he published more than 100 books, and one of them, The Emperor and the Proletariat (Tennô to puroretaria) sold more than one million copies. Through his publications, his academic position, and his leadership of a religious association in the 1950s, Satomi was in a position to influence public opinion. ${ }^{38}$

Satomi's draft would have returned to the prewar state's prerogative to distinguish authentic from "inauthentic," "constructive" from "evil" religions, and superstition from genuine religious belief. In other words, the state should define religion and suppress negative elements in the religious world. Furthermore, the state and the emperor are stated to "transcend" (chōetsu) religion, an expression resembling in tone the Meiji constitution's positioning of the emperor as "sacred and inviolable."

Satomi distinguishes "ancient rites of state" (kuni no kōgi 国の 古儀) from religion. Thus, he reverts to the notion that imperial ritual and (at least some) shrine rites cannot be considered religious in nature. Unlike the prewar state, however, which tended to promote civic observance of such rites by coercive means, Satomi holds in his articles 21 and 22 that shrines may not compel belief in their rites. He singles out imperial enthronement ritual and the rites of the Ise Shrines as particularly authoritative, and reserves the possibility that a general law on shrines might designate additional shrines as comparably authoritative.

In his article 47, Satomi upholds the postwar constitution's prohibition on religious acts by the state, with the important exception of national funerals or memorials. 
Presumably the memorial rites in question would address the deaths of members of the former military and members of the imperial household, though the matter is not completely clarified. His insistence that such memorial rites incorporate the religious beliefs of those being memorialized (or their descendants) is quite distinctive and contrasts strikingly with the practice of the Yasukuni Shrine and the former Nation-Protecting Shrines (gokoku jinja). By contrast, in his article 48 Satomi mandates the state to conduct religious education throughout the compulsory education system in order to nurture respect for religion, a position completely the opposite of that seen in the postwar constitution.

It seems to me that these two articles potentially conflict with each other, inasmuch as religious education could be construed as a kind of "religious act" of the state, which is prohibited under article 47 but mandated under article 48 . Satomi was a strong advocate of unconditional religious freedom (article 46), but he does not recognize the contradiction between that position and the proposal to empower the state to determine what qualifies as "genuine" religion and to suppress groups deviating from state-approved guidelines (article 20). What would happen to the religious freedom of believers in groups deemed "superstitious" by the state?

The Satomi draft stands out as containing substantive proposals, some in the spirit of a return to official recognition of imperial ritual and a status for some shrines and their rites that would be elevated above the category of religion, but without the prewar element of coercion, and with a strong commitment to the idea of religious freedom.

The drafts for a revised constitution issued in the years 1949 to 1958 coincided with the so-called "rush hour of the gods," when a large number of new religious movements 
were being founded or revived after state suppression before the war's end. In these same years there were many incidents in which such new religions were accused or convicted of serious crimes. For example, SCAP raided the headquarters of Reiyūkai Kyōdan in 1949 on suspicion of possession of cocaine and gold bullion. ${ }^{39}$

Also, numerous new religions were entering electoral politics to help their members gain political office, culminating in the 1964 creation of Kōmeitō, the political party sponsored by the Buddhist new religion Sōka Gakkai. The number and membership of the new religions were increasing at unprecedented rates. Although these factors together might well have stimulated proposals for some return to state regulation of religion, in fact the drafts from this period are devoid of such proposals. Instead, they are remarkable for their tolerant attitudes towards religion.

\section{Contemporary Religious Groups' Opposition to Constitutional Revision}

In 2005 the Liberal Democratic Party (LDP) promulgated its draft for a revised constitution, including recommendations for significantly weakening article 9. Significant changes to article 9 will contravene the commitment to pacifism expressed by virtually all Japanese religions. Article 9 is regarded by new religious movements and Christianity, especially, and in many Buddhist circles as well, as sacred, as an article of faith, and any move to revise it in any form will be taken as an evil assault upon all people of conscience. The recent proclamation by the Christian group Mukyōkai, founded by Uchimura Kanzō, "The Gospel of Jesus Christ and the Peace Constitution," illustrates this attitude. This document asserts that the constitution is a precious jewel given by God to all humanity, and that it is the will of Jesus to uphold it. ${ }^{40}$ 
The LDP proposes a loosening of the wording of article 20 , so that rites and rituals that might derive historically from Buddhism or Shinto, but which have become customary and thus lost religious significance, are not prohibited from being performed and financed by public funds ${ }^{41}$ The intention presumably is to declare constitutional the ground breaking ceremonies and memorial ceremonies widely performed in Japanese cities and towns with the mayor and other elected officials participating. This proposed relaxation of the separation clause implicitly raises the question of the Yasukuni Shrine, but the shrine is not explicitly singled out in any of the LDP's documents thus far.

Since 1945, Japanese religions other than Shinto have mainly resisted attempts to weaken a strict reading of the separation clause. Numerous religious organizations in Japan today were prosecuted before 1945 on charges that their doctrines or practices constituted lèse majesté because they were seen as insulting to the emperor or to Shinto. For these organizations, especially, reassertions that Shinto ritual has some part to play in democratic government will be highly objectionable.

In the LDP's revision, imperial ceremonial at court (kyūchū saishi) would be designated "public" in character, paving the way for underwriting such large-scale rituals as imperial enthronement rites from tax revenues. While imperial rites at court are clearly specified, this new wording raises the question whether any other institutions where the emperor performed "public" rites could acquire a "public" character itself. If "national history and tradition" set the standard, as the annotation has it, then the door is open for renewed attempts to declare the Yasukuni Shrine a public institution or to fund the 20-year rebuilding of the Ise Shrines, as some traditionalists hope. ${ }^{42}$ 
Although it is possible to predict to some extent how the religious world will react to constitutional revision, the spectrum of contemporary Japanese religious organizations incorporates significant diversity of opinion on these issues. Also relevant is the fact that different religions have different histories and styles of involving themselves in civil society and its debates. Shinto has consistently advocated constitutional revision, and we may expect that it will welcome the LDP's proposals, perhaps advocating even more thoroughgoing changes. In particular, the Association of Shinto Shrines will undoubtedly welcome any change that would enable the Yasukuni Shrine to be given an official status as the nation's premier facility for honoring the military dead. By contrast, Christianity (both in the form of individual churches, denominations, related organizations of Christians, and the several newspapers published under Christian auspices), and those new religious movements belonging to the Association of New Religions (Shinshūren) will certainly oppose constitutional revision in favor of their expressed commitment to pacifism and a strict separation of religion from state. Yet even among Shinshūren-affiliated new religions, there are some that might wish to see pacifism strictly upheld but would yet welcome a change in the emperor's position. New Age groups and new religious movements tending to withdraw from society may find it difficult to enter civil society discourse on these issues, but it would also be difficult for them to remain credible to their followers if they failed to adopt a position of some kind.

It is not clear that there will be a unified response from the Buddhist sects as such. If they follow their own precedents, they will probably adopt an ostrich approach. Nevertheless, the several associations of Buddhist groups and the newspapers they publish will eventually have to adopt a public position. Recent trends towards greater Buddhist 
engagement with civil society can be seen in Buddhist NGOs, some of which are crosssectarian, and several of which have cooperated with Christians to oppose the United States' wars in Afghanistan and Iraq.

\section{The LDP's 2012 Constitutional Draft}

In April 2012 the LDP issued a second draft for a revised constitution, to coincide with the sixtieth anniversary of the San Francisco Peace Treaty. It proposes the following wording for new articles 20 and 89 (italicized portions represent changes to the wording of the postwar constitution):

Article 20: Religious freedom is guaranteed. The state may not grant special privileges to any religious organization.

2. No person shall be compelled to take part in any religious act, celebration, rite, or practice.

3. The State and its organs shall refrain from religious education or any other religious activity. However, those observances not transcending the boundaries of social ceremonies or customary actions are not to be restricted under this provision.

Article 89: No public money or other property shall be expended for the use, benefit, or maintenance of any organization or group conducting religious activities, with the exception of cases noted in clause 3 of article 20.

On the surface, the new wording in this draft merely incorporates postwar Supreme Court interpretations of the separation of religion from state. One of the most influential rulings stemmed from a 1965 case: When the city of Tsu (Mie Prefecture) held a Shinto ceremony called a jichinsai (grounds purification ceremony) to inaugurate construction of a city gymnasium, a member of the city council raised a lawsuit, claiming violation of articles 20 and 89. The district court found for the plaintiff, but the appeals court reversed that verdict, and the case went to the Supreme Court. The high court's 1977 ruling, which has become a standard, ruled that no total separation of religion from state is possible, but 
that activity "whose purpose carries a religious meaning, and whose effect is to support, encourage, encourage, or promote religion, or to oppress or interfere with it" is prohibited. The standard established is referred to as the "purpose and effect standard" (mokutekikōka kijun). By this understanding, there can exist "ceremonies" which are not "religious," because some rituals like jichinsai have become more "customary" in nature, weakening their religious meaning.

The Tsu case introduced an important distinction between religious and customary ceremonies that allows local governments to use public funds to conduct rites performed by shrine priests. The case is particularly significant in opening a role for postwar public ceremonies deriving from Shinto and in rekindling ideas about the relevance of Shinto to all Japanese, regardless of their (other) religious beliefs. In political terms, the LDP's proposal for revisions to articles 20 and 89 can be seen as a coded message to its most traditionalist supporters, suggesting the party's willingness to continue the debate over whether state support should be restored to the Yasukuni Shrine.

The voters returned the LDP to power in a landslide victory in December 2012. Prime Minister Abe Shinzō, who previously served as prime minister from 9.26.2007 to 2.26.2007, worked tirelessly during his first term to promote constitutional revision. He succeeded in passing a bill that makes possible a popular referendum on constitutional revision, and constitutional revision was part of his re-election platform in 2012. It is his stated intention to promote the issue further during his current term in office. 
${ }^{1}$ The guide to Holtom's papers at the Claremont College provides the following biographical information: "Daniel Clarence Holtom was among the first American scholars to study Shinto in Japan. He was born in Michigan in 1884, earned degrees from Kalamazoo College, The University of Chicago, and Newton Theological Seminary. He was ordained in the Baptist ministry in 1910 and went immediately to Japan as a missionary. In Japan he was professor of modern languages at Tokyo Gakuin, professor of church history in the Tokyo Japanese Theological Seminary, and professor of the history of religion and church history in the Kanto Gakuin of Yokohama. Dr. Holtom was dean of theology in the Aoyama Gakuin of Tokyo from 19361940. When he returned to the United States he was Haskell Lecturer at The University of Chicago then lectured at Colgate-Rochester Divinity School and taught Japanese language at Redlands University. He died in 1962 in San Gabriel, California." See http://www.oac.cdlib.org/findaid/ark:/13030/kt1s2023xp/.

${ }^{2}$ University of Chicago Press.

${ }^{3}$ Its most important members involved in drafting policies for Japan were the international relations specialist George H. Blakesley and historian of Japan at Columbia University, Hugh Borton.

${ }^{4}$ Shintō no tokken haishi, are kara 15 nen. Asahi shinbun 1959.8.2, p. 2.

${ }^{5}$ Bunce had a Ph.D. in history, had been an English teacher in a Japanese high school from 1936 to 1939, and was married to a woman whose parents were Protestant missionaries.

${ }^{6}$ Woodward had advanced training in religion from Union Theological Seminary and had been a missionary in Japan for the Congregational Christian Churches from 1921 to 1941. See Mark Mullins. 2010. How Yasukuni Shrine Survived the Occupation: A Critical Examination of Popular Claims. Monumenta Nipponica 65/1: 108110.

7 Konoe Fumimaro (1891-1945) had served three times as prime minister before the surrender, helping to form Japan's alliance with the Axis powers.

${ }^{8}$ It identified the Yasukuni, Meiji, Nogi, Tōgō, and other shrines as centers of nationalism and noted that these shrines might possibly be closed without violating the principle of religious freedom, since the Japanese government had consistently taken the line that shrines are not religious.

${ }^{9}$ Mullins 2010: 103.

${ }^{10}$ It seems likely that Bunce also read the English works of Katō Genchi and Kōno Seizō on mikadoism published in the English-language journal at Sophia University in Tokyo, Monumenta Nipponica. On numerous occasions he consulted with scholar of Zen Buddhism, D.T. Suzuki and Miyaji Naokazu, of the Jingiin and Chair for Shinto Studies at Tokyo Imperial University.

11 Mullins 2010: 111-118.

12 Mullins 2010: 113.

13 Mullins 2010: 114-116.

${ }^{14}$ Woodward, 1972, p. 69.

15 Takashima Beihō, "Jinja wa shūkyō ni arazu" Asahi shinbun Nov. 12, 1945, p.2. This article is translated in Creemers, Wilhemus. 1968. Shrine Shinto After World War II. Leiden: E.J. Brill, pp. 51-52. The author of the piece is misidentified in Creemers' work as Takashima Yoshimine.

16 The following account is based on the staff study as reprinted in Woodward, 1972, pp. 322-341.

17 Ibid., p. 324.

18 The report introduces distinctions between "State Shinto" and "Sect Shinto." Without formally defining "State Shinto," Bunce seemed to use the term to designate all aspects of Shinto but the sects. For all practical purposes, State Shinto and Shrine Shinto were interchangeable terms in the Shinto Directive.

19 Woodward, 1972: 298.

20 Woodward, 1972, p. 69.

21 Woodward, 1972: 69-72; 106-109.

22 Shinto to tennōsei. Yomiuri shinbun 18 December 1945, p. 1.

${ }^{23}$ AG 003 (6 Nov. 1946) CIE, APO 500 (SCAPIN 1318).

${ }^{24}$ Quoted in Woodward, 1972, p. 128.

25 Dower, John. 1999. Embracing Defeat: Japan in the Wake of World War II. (W.W. Noarton \& Company, Inc.), pp. 351-360.

${ }^{26}$ Charles L. Kades Papers [microform] [between 1946 and 1948] Harvard University Libraries, Film W23975.

${ }^{27}$ Harry Emerson Wildes (1890-1982), clergyman, sociologist, and biographer of George Fox and William Penn, took his undergraduate training at Harvard University, graduating in the 1920s, and his Ph.D. from the 
University of Pennsylvania in 1927, working for a time in Japan as a journalist. He resigned from the Occupation in late 1946, disillusioned with American arrogance. He went on to write Typhoon Over Tokyo: The Occupation of Japan and Its Aftermath (New York: Macmillan, 1954).

${ }^{28}$ Sirota's father had come to the country as an orchestra conductor and remained as a university teacher of music.

${ }^{29}$ Roest was a Dutch American partly educated in Holland; Tadashi Aruga. The Declaration of Independence in Japan: Translation and Transplantation, 1854-1997"

http://chnm.gmu.edu/declaration/japanese/aruga2.html, accessed May 19, 2012.

30 Dower, 1999, pp. 364-365.

31 The document contains no discussion of article 89.

32 Alfred R. Hussey, Jr., one of the lawyers of the group.

33 "Steering Committee Minutes - 5, 6, 7, 8, 9, 11 and 12 February 1946," pp. 14-15, Charles L. Kades Papers [microform] [between 1946 and 1948] Harvard University Libraries, Film W23975.

34 This finding seems very odd to me; I will try to devise other search techniques that might turn up some relevant discussion, but at this stage of research, I have failed to find any.

35 Tanaka Nobuyoshi. 2005. Kenpō kyūjō no sengoshi. Tokyo: Iwanami shinsho 951, pp. 11-13, 48-53.

${ }^{36}$ Chōsa rippō kōsa kyoku, Hōritsu seiji toshokan dai-ni ka.. 1956. Nihon koku kenpō seitei keika nichiroku (miteikō no san). Tokyo: National Diet Library of Japan.

${ }^{37}$ Kenpō Chōsakai Jimukyoku, ed. 1959. Nihonkoku kenpō kaisei shōan (Tokyo).

${ }^{38}$ Here are his proposals for religion:

Article 20: Protection of Religion, The Emperor's and the State's Transcendence of Sect, Prohibition on Authoritarian Interference

Recognizing the importance of religion in the spiritual life of humanity, the state shall protect all religious sects possessing legitimate religious values equally.

2. The emperor and the state transcend all religious sects and do not give special protection to any sect or religious organization.

3 . The state must not interfere with any religious sect or religious organization, or with any believer, belief, doctrine, ceremony or other assembly or internal system, so long as it does not contravene this constitution.

4. The state may suppress superstition, heterodox places of worship, and evil religions where prescribed by law.

Article 21 Ancient State Rites

Imperial enthronement (the Daijō-e) and other rites transmitted within the imperial

household are ancient state rites and are to be distinguished from sectarian religious action.

Article 22 The Ise Grand Shrine and Shrines

The Ise Grand Shrine and shrines so designated in law are facilities for the performance of ancient state rites.

2. In accord with the previous article, the Grand Shrine and other shrines play a role in naturally harmonizing the people, receiving their freely accorded respect and reverence. The shrines must not preach or coerce belief in particular doctrines nor criticize or slander the rituals, doctrines, or

beliefs of other religions. Each shrine rite based upon that shrine's original traditions is to be recognized as preserving the spirit of the ancient customs of the people. Details will be found in the Grand Shrine and Shrines Law (to be enacted as law).

Article 46 Freedom of Religious Faith

There are no limitations on the people's freedom to choose to have or not have religious faith, and to choose a religious sect or not.

2. All persons are free to participate or not in religious activity, ceremonies, rites, and observances; they may not be compelled in these matters.

3. No religious sect or religious organization may receive political privilege. 
Article 47 Prohibition on Religious Activity by the State and Exceptions

Neither the state, its organs, nor any public organization may perform religious activity of any kind, with the exceptions noted in the following article.

2. National funerals, funeral and memorial rites sponsored and carried out by government offices must be based upon the faith and beliefs of the person(s) receiving the funeral or their bereaved relatives. If they wish to have these rites performed in the manner of a specific religious sect, that wish must be respected and incorporated into the ceremony.

Article 48 Religious Education Conducted by the State

Throughout compulsory education, the state must nurture attitudes of religious respect among the people through teaching that constructive religions must be revered.

${ }^{39}$ Other events involving such groups suggested that provisions for religious freedom might be exploited to shield the founders from prosecution, as for example the founding in 1950 of Higashikuni-kyô (ひがしくに教 ) by former Prime Minister Higashikuni Naruhiko, who had presided over the signing of the articles of surrender but later resigned in opposition to Occupation orders to rescind the Peace Preservation Law of 1925 and to dissolve the Special Police. There were numerous prosecutions of these groups for tax evasion during these years.

40 "Iesu Kirisuto no fukuin to heiwa kenpô" Kirisuto shinbun 11.27.2004, p. 2.

${ }^{41}$ Precedents from Supreme Court rulings would set the standard for determining which customary rites are permitted.

42 This measure opens the way to expectations that foreign ambassadors would also play a role or make their own observances at Yasukuni. 